This item was submitted to Loughborough's Research Repository by the author.

Items in Figshare are protected by copyright, with all rights reserved, unless otherwise indicated.

\title{
Julie and the cybermums: marketing and women voters in the UK 2010
} General Election

PLEASE CITE THE PUBLISHED VERSION

http://dx.doi.org/10.1080/15377857.2013.781472

PUBLISHER

(C) Taylor and Francis

VERSION

AM (Accepted Manuscript)

LICENCE

CC BY-NC-ND 4.0

\section{REPOSITORY RECORD}

Harmer, Emily, and Dominic Wring. 2019. "Julie and the Cybermums: Marketing and Women Voters in the UK 2010 General Election”. figshare. https://hdl.handle.net/2134/13444. 
This item was submitted to Loughborough's Institutional Repository (https://dspace.lboro.ac.uk/) by the author and is made available under the following Creative Commons Licence conditions.

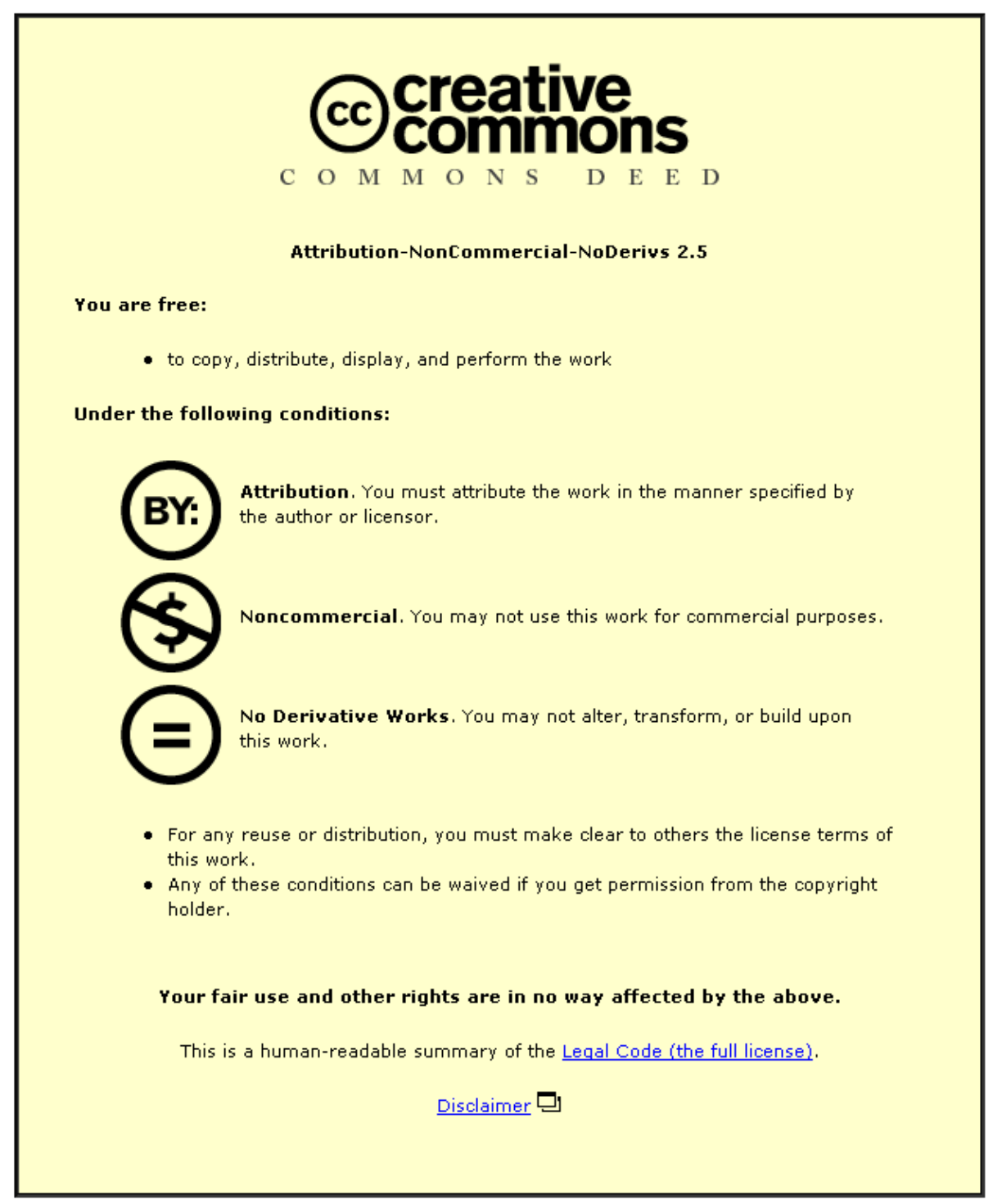

For the full text of this licence, please go to: http://creativecommons.org/licenses/by-nc-nd/2.5/ 


\title{
Emily Harmer and Dominic Wring
}

\section{Julie and the Cybermums: marketing and women voters in the UK 2010 General Election}

\begin{abstract}
Certain groups of female voters have long been recognised as potentially vital to deciding the outcome of elections. This paper explores and compares efforts made by the British Conservatives to focus on addressing the concerns of mothers with children. The party made a significant attempt to cultivate this kind of woman during the 2010 campaign through the use of a lay person, Julie, whose personal testimony and image was central to this effort. Here comparisons are drawn with the intriguingly similar figure of Sylvia used by the Conservatives 40 years before. Discussion also focuses on another important gendered aspect of the election relating to the growth of new social media platforms and, more especially, how they are represented through the still important medium of agenda-setting newspapers to promote certain perspectives that can be highly partisan in their selectivity if not their intent.
\end{abstract}

Keywords: women, voters, campaigning, targeting, new media

Emily Harmer is a Doctoral Candidate at Loughborough University

Dominic Wring is Reader in Political Communication at Loughborough University.

Address for Correspondence: Dr D Wring, School of Social, Political \& Geographical Sciences, Loughborough University, Leicestershire, United Kingdom LE11 3TU. Tel 00441509 228350, D.J.Wring@lboro.ac.uk 


\section{Introduction}

Women have long been identified as a key electoral target group. This is not just because they are intrinsically important given their sizeable numbers and propensity to vote: rather it refers to the way successive generations of party strategists have identified and sought to cultivate the female electorate with tailored appeals. This kind of targeting, which stretches back over the course of the Twentieth Century, has become a more prominent aspect of electioneering in recent decades. In 2010 this was a particularly marked feature of the campaign and the role and depiction of women in the general election threw up some contradictory representations. Women, particularly the leaders' wives, were ubiquitous during the campaign in a way that departed from any previous campaign (see, for instance, Higgins and Smith in this volume). Conversely female politicians seemed conspicuous by their absence. Obviously this was not helped by the fact that the brand new Prime Ministerial Debates featured only men as protagonists, be these the party leaders or the journalists chairing these televised proceedings. And this in turn was one of the reasons why there was an especially personal, presidential focus in this election as the incumbent premier Gordon Brown attempted to appear as the statesman who had taken the difficult economic decisions and got them right.

Like his principal rival David Cameron, Gordon Brown was routinely accompanied by his wife Sarah, herself a former public relations consultant who had left her own lucrative career to devote herself fulltime to her family. By contrast other leading Labour women, notably deputy leader Harriet Harman and her Cabinet colleague Yvette Cooper, appeared marginal figures in news reporting terms. At one press conference Cooper and a male colleague, Liam Byrne, were inadvertently caught by a camera writing notes to each other bemoaning their 
essentially decorative, 'second division' status. The lack of prominent elite female figures during the campaign was arguably a by-product of the party strategists' own approach as well as news media reporting. Evidently this absence, perhaps compensated by the involvement of the leaders' wives, was apparently not seen as an impediment to cultivating women voters. The latter were ever present in the strategic formulations and this paper considers some of the ways in which the major parties attempted to engage with a female audience.

\section{Targeting Women}

In electoral terms women are viewed as more persuadable because they are less likely to identify with a particular party (Campbell, 2006). During their 'new' incarnations during the 1990s the US Democrats and British Labour focused a considerable amount of their campaigning activities on winning the support of the so-called 'Soccer Mums' and ‘Worcester Women’ respectively. Both were exemplars of those who perceived themselves, or aspired to be, part of so-called 'Middle America/England' vote. This period highlighted both the strategic focus on the importance of key groups of 'swing' voters as well as the gendered dimension to such approaches. Subsequent British elections have featured extensive discussions of different segments including, in 2005 alone, 'let down woman' (Campbell and Lovenduski, 2005), 'school gate mums' (Deacon et al, 2007) and 'Sandwich Mothers’ (Childs, 2005). 2010 would be little different.

Political strategists, particularly since the rebranding of Labour as 'new', have tended not to focus on simply cultivating what was once commonly referred to as 'the working-class'. Consequently various proxies for this group have included the media they traditionally 
consume such as Sun readers or, more recently, Take a Break woman. The latter group were readers of the best-selling weekly magazine that had featured prominently in coverage of the 2005 election. Labour Campaign Co-ordinator for 2010 Douglas Alexander suggested these voters were a key target audience category and described a typical representative of them as 'under 40... (S)he's likely to be a homeowner living in a household with children, living in a small city or town. These women are likely to live in the Midlands in the new towns and in the M1 corridor. They work full-time and part-time and in retail in particular. Both parents are working' (The Sunday Times, $4^{\text {th }}$ April 2010). Labour were keen to target in this way because they estimated 400,000 young mothers from 100 marginal constituencies could determine the overall election result.

More conventional brands demonstrated a preparedness to integrate the election into their gendered marketing activities. Consequently the world's largest supermarket group exported its 'Wal-mart Moms' campaign intervention in the 2008 US presidential race to Britain and enabled the major parties a chance to reach customers who were mothers. The company website videos featuring David Cameron as well as Gordon Brown who declared it was 'a pleasure to be talking to Asda Mums' (Daily Telegraph, $13^{\text {th }}$ April 2010). Whilst the aforementioned campaigns explicitly focused on their targets' parenthood, other gendered and brand related niches such as the so-called 'Lambrini Ladies' appeared in media reports as a more hedonistic group of younger female drinkers with active social lives (Fielding, 2010). Additionally the routine construction of women as mothers was reflected in the major party campaigns. Labour promoted their flagship Sure Start policy with its integrated services covering childcare, educational, health and other support services for families with dependents under five. Prior to the announcement of the election the party dispatched several direct mailing leaflets that featured a young mother of two children and claimed that the 
Conservatives wanted to cut this provision. This effort was followed up with visits by leading figures including Gordon Brown and his deputy Harriet Harman to Sure Start centres around the country in an attempt to remind core Labour supporters that the policy exemplified the party’s continuing commitment to redistributive measures.

The Conservatives also attempted to appeal to women whose concerns were similarly and routinely equated with motherhood. The party manifesto proclaimed its desire to 'make Britain the most family-friendly country in Europe' by introducing measures such as reforming the tax and benefits systems to better recognise marriage, extending the right to request flexible working hours, and by introducing more entitlements to paternity leave for fathers (Conservative Party, 2010, p. 41). Unlike Labour they had far greater resources to mount campaigns aimed at this and other specific target groups of voters. Several of these featured in films and other forms of publicity on the party website. Three principal characters emerged and were also heavily promoted through outdoor 'I've Never Voted Tory Before' poster advertising as well in Party Election Broadcasting: a married father, a young black woman involved in volunteering and, perhaps, most prominently a family oriented mother of two. The portrayal of the man, 'Ian', is intriguing because on the surface he appears to be an archetypal skilled worker wearing blue overalls in a workshop in an image captioned 'I've never voted Tory before, but we need to sort out the economy' that was strikingly similar to the man featured half a Century earlier in the 1959 party advert 'You're looking at a Conservative'. However the accompanying PEB and extended film version available online clarifies Ian is in fact a small businessman who employs a team of engineers rather than conventionally working-class as the poster implies. 


\section{'I've Never Voted Tory Before'}

Arguably the most high profile aspect of the 'I've Never Voted Tory Before' campaign was that featuring Julie from Llandudno, a photogenic representative of another key target group: mothers with school age children. The woman in the advertisement, Julie Fallon-Smith (or simply Smith according to the party), was depicted in the poster along with her son and daughter with the tagline 'I’ve never voted Tory before but I like their plans to help families' in a photograph that was obviously designed to counteract some of the similar images in Labour's Sure Start campaign. The image was again reminiscent of yet another illustration used in the 1959 campaign: 'Life's Better with the Conservatives: Don't Let Labour Ruin It' which had, as its focus, a picture of idyllic family life. Julie, like Ian, also featured in an online video and Party Election Broadcast in a film that explained she was married with two children and worked part-time in a department store to supplement her husband's earnings. The election did not mark her political debut as she had previously appeared in promotional material at least six months prior to polling day. In a Party Political Broadcast of $18^{\text {th }}$ November 2009 Julie had first been shown attending a meeting of Cameron Direct, a round the country tour by the leader, and commenting: 'I'm considering [the] Conservative partly because I feel that I didn't vote for Gordon Brown, I don't think he’s done a particularly good job and I'm looking for an alternative'.

Evidently Julie had firmed up her intentions by the time she began appearing in Tory promotional material to proclaim her priorities were quite general and related to the valence issues of education and a decent society in which her children can grow up. Ironically the message is problematic given Julie lives in North Wales and schools and related policies are largely determined by the Cardiff based National Assembly and not Westminster. 
Nonetheless she continued to feature prominently in the early stages of the election proper and was noticeably visible, along with Ian, as one of the voters who sat alongside Conservative luminaries on the platform as David Cameron and his colleagues launched the party manifesto entitled ‘An Invitation to Join the Government of Britain’. Significantly film of Julie was presented as part of the preamble to the formalities, and a photograph and quote of hers were reproduced where the document discussed Britain's changing society (Conservative Party, 2010, p.40).

The promotional use of a married, working mother to appeal to women voters is nothing new. During the 1970 campaign the Conservatives produced a Party Election Broadcast (PEB) of this kind that was also noteworthy because it focused on the experiences of an ordinary voter. The individual in question, Sylvia, was designed to be representative of the working class housewife whose husband routinely votes Labour and who might be persuaded to vote Conservative because of the rising cost of living under the incumbent government. Implicit in this was an assumption that this group had not been cultivated before because it had been assumed they would share their husband's choice (Day, 1982; Rosenbaum, 1997, p.57). The Tories responded by targeting these women through promoting the theme of 'the shopping basket election' and the power of this particular metaphor was later demonstrated by its use in 1974 by Labour's Shirley Williams and again by the now Tory leader Margaret Thatcher in 1979.

The PEB featuring Sylvia begins with a couple of unnamed women making remarks to camera about politicians: 'they don't understand a woman's point of view' and 'they never think about, well, a normal housewife's budget'. On screen one of the two Conservative MPs 
presenting the Broadcast, Geoffrey Johnson Smith, argues 'for the first time a general election will be decided not just by the party faithful, but by a hidden majority who traditionally have voted by habit but now seen determined to vote by conviction - the British housewife'. His colleague Christopher Chataway agrees, commenting 'the housewife feels she has been taken for granted'. Here and elsewhere there are striking parallels with the 2010 equivalent which are more than just about the two protagonists' very dark hair. David Cameron himself introduces the latter film 'this is Julie, voting for stronger families' and a minute of footage showing her caring for her children, doing housework and volunteering in a charity shop. The clip closes with Cameron saying 'I want to help mothers like Julie supporting the strong families that are the bedrock of a strong society'. Neither Broadcast is alarmist but both are evidently motivated by their respective preceding economic crises of 1967 and 2008.

The two films concentrate on the women as mothers and their domesticity rather than their paid employment. Sylvia is described as a 'working housewife' and shown in an office environment typing and answering the phone whereas Julie explains that 'as well as being a mum, I work three days a week in a department store and it's nice to have that work-life balance'. Despite being made 40 years apart and with production values that suit the respective periods, both Broadcasts feature material that could be used in either film. Julie is initially shown at home and then at the breakfast table with her children, driving them to school, walking the dog and tidying her daughter's bedroom. Her husband is absent from the visuals but is mentioned, thereby underlining the fact that this is a so-called 'nuclear' family set up. Similarly with Sylvia her partner is unseen but his existence is acknowledged from the starting commentary which announces: 'Name: Sylvia. Age: twenty-two. Occupation: 
working housewife with one child'. She is shown taking her young son to the park and gazing through high street shop windows.

\section{The Political gets Personal}

If the Julie and Sylvia characters share some features, the two women's rhetoric is also similar, albeit the 1970 version places more emphasis on escalating prices, a key issue for the protagonist: 'everything you go to buy, washing powder, washing-up liquid, everything's risen tremendously. I used to go into the shops and get my weekend shopping and there's a matter of about two pound difference now... things would be a lot better under the Conservatives'. Similarly Julie offers the following 'it's time for change in this country, I think that under Labour we're heading in the wrong direction. I think that they haven't got it right with children... their policies on family are the best thing for my future and my children's future'. Whilst Sylvia's aspirations are more material security through a house and washing machine, Julie again focuses on family: 'I want my children to grow up in a society where people don't have a negative opinion of children, where they don't just think of children as misbehaving. I want the country to go back to where it used to be where family was important and children were seen as a nice part of society... I think that the Tories have great policies and I believe that their policies on family are the best thing for my future and my children’s future'.

The aforementioned extracts and the rest of the Broadcasts are characterised by their vagueness and this is undoubtedly part of a conscious strategy not to offer a policy rich message; rather the focus is on demonstrating that women who are representative of this 
particular target group of voters are moving towards the Conservatives. In 2010 this was hardly a new strategy but in 1970 it was something of a departure and all the more important because it came during one of the most keenly fought elections of all time. It would be churlish to suggest that the Sylvia campaign tipped the balance in the Conservatives' favour but it arguably made a contribution by presenting the party in a way that might have resonated with sections of the electorate in a way that differed from conventional political interventions.

Social class is central to both films since they aim to appeal to women who would not necessarily have voted Conservative before. The protagonists identify themselves as being working class. In Sylvia's case, this is the explicit reason for her inclusion in the PEB in the first place, in order to appeal to working class housewives as a segment (Day, 1982). Arguably, Julie was also selected for this reason and she speaks explicitly about her past political outlook, "I never thought growing up that I would vote Conservative, I have to be honest. I guess I saw them as the posh party and I consider myself very much working class, but I believe that's changed now. I think their policies are very much about everybody.” This statement appears calculated to address and rebut historic criticisms that the party is dominated by the privileged and therefore unrepresentative of the majority of the electorate. It also serves to promote the idea that Cameron has reformed the party, making it more responsive to the concerns of the ordinary voter. Julie reinforces this message by making it clear that the party must have changed or she, an ordinary working class voter would not be considering them seriously. Sylvia fulfils a similar function in the 1970 broadcast when she states “a working person has always voted Labour but I think a lot of people have changed their mind now and won't vote Labour again." She explains that she feels let down by their failure to keep down the cost of living and their poor management of industrial relations. 
The films featuring Julie and Sylvia attempt to address women specifically, whilst simultaneously acknowledging their status as wives. Both women mention their husbands throughout the film, but neither man makes an appearance. Sylvia's husband is revealed to be a lifelong Labour voter who is likely to continue voting in this way, so would obviously not want to appear in a Conservative PEB. Sylvia explains that she is determined to vote Tory even though her "husband will vote Labour because he's always voted Labour and generations before him have voted Labour”. This reflects the aim of the Broadcast, which was to separate women from their husbands voting intentions so he would have been omitted intentionally. In Julie's case, this is much less clear. She mentions that her husband is a shift worker, though his role is not, however, made explicit. Julie does not allude to her husband's voting intentions, she and her children only mentions him in relation to their daily routine. Sylvia and Julie are constructed as mothers and wives who have discreet political views from those of their partners, but nevertheless these priorities are informed by their familial relationships.

Despite the startling similarities between the films made forty years apart, there are some notable contrasts that reflect the differing objectives of the Broadcasts. Julie's message is overwhelmingly positive and this reflects David Cameron's attempt to offer an optimistic, upbeat message to the public. By contrast, Sylvia's narrative presents a bleak picture of how her struggling household has been neglected by the government. The failings of the incumbent Labour and its alleged responsibility for the economic crisis could have also framed Julie's testimony but she tends to avoid these more direct accusations in favour of promoting the Conservatives' theme of the 'Big Society' and a proposed "National Citizen 
Service” (Conservative Party Manifesto, 2010, p.38-39). . A seemingly model citizen, she is shown volunteering in a local charity shop which 'helps disabled children' where she helps out "sometimes" because "it's very important for me to be involved in the local community because this is where my children are going to grow up.”

\section{Mumsnet versus Netmums}

The run up to the 2010 campaign was characterised by politicians engaging with what they perceived to be female concerns and the advertising using the role model of Julie was the most high profile, resource intensive aspect of this effort. The rival parties also invested in public relations or 'spin' activities to court women voters and a good deal of this work focused on the burgeoning parenting websites, most notably the near namesake rivals Mumsnet and Netmums. Consequently the so-called “cyberwoman” (The Independent, $18^{\text {th }}$ November 2009) or just plain 'cybermums' (The Sun, $21^{\text {st }}$ November 2009) were quickly identified in media reports as potentially important electoral audiences. Crucially they were perceived to be an active, mobilising force; perhaps somewhat predictably, given ongoing hype about this being the 'first internet campaign', this led to suggestions that this was also going to be the 'Mumsnet Election' (The Times, $17^{\text {th }}$ November 2009). Journalistic reporting of elections is prone to neologisms and media preoccupation with online campaigning overlooked there had been similar developments in 2005 with a Netmums' delegation appearing on successive editions of the light entertainment GMTV breakfast programme to interrogate each of the three main party leaders. The same source also provided guests for other fora and conducted its own member surveys, some of which attracted media interest (The Times, $16^{\text {th }}$ April 2005). 
During the months leading up to the 2010 election the three main leaders along with other luminaries such as Green Party leader Caroline Lucas, Conservative spokesperson Michael Gove and Labour Cabinet member Yvette Cooper took part in live online chats with Mumsnet users in which they answered questions about their personal lives as well as politics. The Prime Minister's wife Sarah Brown also took part in a 'webchat' and was identified as a registered user of the same site. Yet despite all this activity, the majority of it initiated by politicians, the most memorable and reported interaction came with the apparent refusal by Gordon Brown to answer a question about his favourite biscuit (The Sunday Times, $18^{\text {th }}$ October 2009; Campbell, 2010). This was, however, an unfair summation of what had been a useful and deeper exploration of a range of topics that reflected on the articulacy of Netmums' founder Siobhan Freegard and her counterparts Justine Roberts and Carrie Longton from the rival Mumsnet. All three became frequent spokespeople for 'cybermums' across a range of mainstream media outlets including one newspaper that acclaimed the latter pair as ‘two women who could decide the next General Election’ (Daily Mirror, $26^{\text {th }}$ January 2010).

The pre-election focus on women and other target voters predictably faded with the onset of the campaign and intensification of the focus on the leaders and their Prime Ministerial Debates. Certain outlets did, nevertheless, continue to feature stories on the topic and many of these promoted one or other of the sites. Netmums, for instance, scored a notable coup when its member survey was quoted in the best selling weekly newspapers as suggesting the Conservatives were 'winning battle for mums' with 33.7\% of respondents indicating they are planning to vote Tory compared to $24.1 \%$ for Labour and $15.8 \%$ Liberal Democrat (News of the World, $18^{\text {th }}$ April 2010). The article stated that if this trend were replicated on election day the Conservatives would win the election because they had 'stormed into a whopping 10 
point lead' in 'today's poll'. A strikingly similar report appeared in Daily Express the following day and repeated the claims made in the original article using very similar language, often with only the occasional word changed. Whether or not these articles resulted from a Netmums press release is unclear. On closer inspection the News of the World and Express' claims appeared misleading because, in the absence of the fieldwork dates and sample data that have been commonly published since the 1992 election, it was difficult to assess the veracity and representativeness of the data that formed the basis for this contention. The paper's figures were the same as the rounded up totals (Conservatives 34\%, Labour 24\% and LibDems 16\%) already published by a rival Sunday newspaper two weeks earlier and based on a 3000 sample of Netmums users (Observer, $4^{\text {th }}$ April 2010). Rather than having 'stormed' into the lead, the poll suggested that Tory support had remained constant and that their rivals were closing the gap. This was because an earlier Netmums' survey of 6000 users, taken between late December to late January, had put the Conservatives on 34\%, Labour $18 \%$ and LibDems $15 \%$ (Sun $27^{\text {th }}$ January 2010; Independent, $28^{\text {th }}$ January 2010). And whereas the larger sample was contemporaneously published by and featured on the Netmums' site the smaller follow-up only appeared in media reports, thereby reinforcing the notion that the Observer, News of the World and Express were referring to the same data.

A third Netmums survey raised similar issues to the previous two when an article solely published in the online version of the paper and headlined 'Mums revolt after Brown gaffe' claimed that ‘Gordon Brown’s bigot gaffe has seen him BOMB in the battle to woo Britain's mothers' (News of the World, $2^{\text {nd }}$ May 2010). The claim, and the Netmums survey of 2067 users it was based upon, were not taken up and discussed elsewhere in the media, perhaps because the apparent collapse in support for Labour to $20.81 \%$ in this poll was out of line with the more traditional polls. Arguably more striking, and something completely 
overlooked in the News of the World report, was the evident in the surge of support for the LibDems amongst this sample which, at 25.44\%, put them marginally ahead of the Conservatives on $25.16 \%$. This example underlines how the media as well as the politicians are prone to using spin to prosecute their case. The growth of online advocacy sites provided ample opportunities to find convenient data to support an argument.

\section{Conclusion}

Targeting has long been an aspect of election campaigning. 2010 witnessed some particularly noteworthy and interesting attempts to engage with various groups of voters. Women, a perennial target audience, were once again subjected to tailored overtures from politicians. The most high profile of these was a carefully prepared campaign featuring a model convert to the Conservative cause called Julie. This explicit appeal to women was not, however, a new approach. The character of Julie was in many ways similar to that of Sylvia, a woman who featured forty years previous in the Tories' highly innovative 1970 campaign. Both featured in highly stylised Party Election Broadcasts that portrayed them, and by extension many floating female voters, as homemakers who also act as the primary carers for their families. Such appeals promoted a highly traditional message that many women's primary role was a domestic one. This theme was reinforced by the marginalisation of female politicians and the marked presence of the party leaders' wives. The latter group's presence in media coverage of the election was encouraged by the introduction to UK elections of the Prime Ministerial Debates, a move that made the campaign an even more presidential affair. 
The three formal debates involving the leaders overshadowed the rest of the campaign and this male bias was augmented by the presence of male presenters facilitating each of these encounters. The women that managed to participate in these programmes did so as some of the questioners present as part of the live studio audience. Party's marketing appeals, especially the most high profile Julie pitch, did little to challenge the construction of female voters as largely passive observers. In sharp contrast the advent of social networking sites afforded opportunities for women, in particular, to more consciously assert themselves in various spheres of public life including the political. During the lead up to the campaign there were the now familiar media stories about the outcome of the 2010 race resting with key segments of the electorate and there was particular fascination with those boasting an online presence. Consequently talk of the 'Mumsnet' election reinforced this perception although some of the resulting press coverage of this site and its more socially conservative Netmums rival was prone to cliché if not the belittling of these actors. Nevertheless the major parties, and their male leaders, saw these and similar forums as a vital means of engaging with women voters and this contributed to promoting the influence of a web presence. Cumulatively this considerable public relations effort combined with advertising messages was markedly devoid of a distinct female presence in terms of the politicians involved. Overall this contributed to an arguably regressive campaign in which women were seen but not much heard.

\section{References}

Campbell, R. (2006) Gender and the Vote in Britain. London: ECPR. 
Campbell, R. (2010) “The Mumsnet Election?” Paper presented at Political Studies Association Annual Conference April 2010, Edinburgh.

Campbell, R. and J. Lovenduski. (2005) “Winning Women’s Votes? The Incremental Track to Equality,” in Norris, P. and C. Wlezien. (ed.) Britain Votes 2005. Oxford: Oxford University Press, pp.181-197.

Cassidy, S. and N. Morris (2010) “Cameron winning female vote for Tories.”, The Independent, $28^{\text {th }}$ January 2010, p.8

Childs, S. (2005) “Feminising British Politics: Sex and Gender in the Election,” in Geddes, A. and J. Tonge. (ed.) Britain Decides: The UK General Election 2005. Basingstoke: Palgrave MacMillan, pp.150-167

Conservative Party, 2010, Tory manifesto

Day, B. (1982) “The Politics of Communication, or the Communication of Politics" in Worcester, R. M. and M. Harrop (eds.) Political Communications: The General Election of 1979. London: George Allen and Unwin.

Deacon, D. Wring, D. Golding, P. (2007) “The Take a Break Campaign? National Print Media Reporting of the Election,” in Wring, D., J. Green, R. Mortimore and S. Atkinson (eds.) Political Communications: the British General Election Campaign of 2005. Basingstoke: Palgrave MacMillan.

Fielding, S. (2010) 'Lambrini Ladies': why the election turns them off', The Guardian, $12^{\text {th }}$ April.

Hall, J. (2010) “Labour seeks a catch of the day in the fresh fish aisle.”, Daily Telegraph, $13^{\text {th }}$ April, p.5

Iggulden, C. (2009) "Politicians need to Net our votes”, The Sun, $21^{\text {st }}$ November, p.24-25

McSmith, A. (2009) “Meet cyberwoman, the battleground for the next election.”, The Independent, $18^{\text {th }}$ November, p.18

McVeigh, T. (2010) "Parties failing to appeal to mothers for election vote.”, Observer, $4^{\text {th }}$ April, p.5

Neil, B. (2010) “Britain’s most powerful mums.”, Daily Mirror, $26^{\text {th }}$ January, p.28-29 
Newton Dunn, T. (2010) “Blue Mums’ day; Tory joy as mothers desert Labour in Election.”, The Sun $27^{\text {th }}$ January, p.12

Oliver, J. (2009) "PM bites the biscuit and names favourite.", The Sunday Times, $18^{\text {th }}$ October, p.3

Oliver, J. (2010) “The Obama Election.”, The Sunday Times, $4^{\text {th }}$ April, p.11

Peake, L. (1997) "Women in the Campaign and in the Commons”, in Geddes, A. and J. Tonge (eds.) Labour’s Landslide. Manchester: Manchester University Press, pp. 165-177.

Ridge, S. and D. Wooding (2010) "Mumifesto backs Cam.”, News of the World, $18^{\text {th }}$ April, p.9

Ridge, S. (2010) "Mums revolt after Brown gaffe.”, News of the World $2^{\text {nd }}$ May: http://blogs.notw.co.uk/politics/2010/05/britains-mums-revolt-after-brown-gaffe.html (accessed 19th August 2010).

Rosenbaum, M. (1997) From Soapbox to Soundbite: Party Political Campaigning in Britain since 1945. Basingstoke: Macmillan.

Sieghart, M. A. and A. Frean (2005) "Why one million school-gate mums can turn the election.”, The Times, $16^{\text {th }}$ April, p.34

Sylvester, R. (2009) “This election will be won at the school gate.”, The Times, $17^{\text {th }}$ November, p.25 